\title{
Morphophysiological biometry and grain production in cowpea under different phosphorus levels
}

\author{
Antonio Aécio de Carvalho Bezerra'*, Raimundo Soares da Costa Filho', \\ Simone Raquel Mendes de Oliveira ${ }^{2}$, Francisco Rodrigues Freire Filho ${ }^{3}$
}

\author{
'Federal University of Piaui, Teresina, Brazil \\ 2Piaui State University, Picos, Brazil \\ ${ }^{3}$ Brazilian Agricultural Research Corporation, Belém, Brazil \\ *Corresponding author, e-mail: aecio@ufpi.edu.br
}

\begin{abstract}
In tropical and semi-arid regions of Brazil, phosphorus is one of the most limiting elements of cowpea productivity. The aim of this study was to assess the effects of applying five phosphorus doses in the soil on morpho-physiological and production components in three improved cultivars of cowpea. The experiment was carried out at the São Fernando farm located in José de Freitas, $\mathrm{Pl}$, Brazil, in a Plinthosol with a low phosphorus content. The experimental design was complete randomized block design with four replications in a $5 \times 3$ factorial scheme consisting of five phosphorus doses $\left(0,60,120,180\right.$, and $\left.240 \mathrm{~kg} \mathrm{P} 2 \mathrm{O} 5 \mathrm{ha}^{-1}\right)$ and three improved cowpea cultivars (BRS Guariba, BRS Tumucumaque, and BRS Cauamé). No interaction was observed between cultivars and phosphorus doses for any of the assessed variables. The cultivar BRS Tumucumaque showed the highest value for one-hundred-grain weight $(21.0 \mathrm{~g})$ and, together with BRS Guariba, the highest value of pod length. An increment was observed in growth (stem diameter, main branch length, leaf area, and shoot dry matter) and production characteristics (number of pods per plant, number of grains per pod, one-hundred-grain weight, and grain production per plant) in response to increases in phosphorus doses. The dose of $183.1 \mathrm{~kg} \mathrm{P}_{2} \mathrm{O}_{5} \mathrm{ha}^{-1}$ provided the maximum technical grain yield, estimated at 2,023.3 $\mathrm{kg} \mathrm{ha}^{-1}$.
\end{abstract}

Keywords: Vigna unguiculata, fertilization, growth, grain yield

\section{Introduction}

Cowpea (Vigna unguiculata (L.) Walp) plays an increasingly important role in the food security of peoples of several tropical and subtropical regions in the world characterized by a high rainfall irregularity and low technological level (Bezerra et al., 2014a).

Due to its nutritional potential, with high contents of protein, energy, fiber, and minerals (Carvalho et al., 2012), as well as due to its ease of production and reaching, cowpea is the main food legume for poor populations of the North and Northeast regions of Brazil, historically characterized by deficiency in energy, protein, and minerals (Bezerra et al., 2014a). However, in these regions, this crop presents low grain yields with averages of 432 and $875 \mathrm{~kg} \mathrm{ha}^{-1}$, respectively (CONAB, 2016).

The low natural phosphorus content in most soils of semi-arid and Cerrado regions that produce cowpea in Brazil contributes significantly to its low productivity in traditional cultivations, which requires soil correction, leading to a great increase in production costs in technified systems. According to Smyth \& Cravo (1990), phosphorus is one of the most important elements for agricultural production in most tropical soils. Adetunji (1995) points out that, even though it is not required in large quantities by the cowpea plant, phosphorus is essential to its production 
due to its multiple effects on plant nutrition.

The direct and positive influence of phosphorus on several morphophysiological and productive characteristics of cowpea are highlighted by Silva et al. (2010), Oliveira et al. (2011), Ndor et al. (2012), Coutinho et al. (2014), and Pereira Júnior et al. (2015), among others. However, the amount, absorption rates, and effects of phosphorus on plants are controlled by physiological characteristics, and thus, species and their cultivars may present different levels of phosphorus requirement for the expression of their maximum production potential.

Therefore, this study aimed to assess the effect of five levels of phosphate fertilization on morpho-physiological and productive characteristics of three cowpea cultivars.

\section{Material and methods}

The experiment was carried out from May to July 2013 under field conditions at the São Fernando farm, located in José de Freitas, PI, Brazil, at the geographical coordinates $04^{\circ} 44^{\prime} 25^{\prime \prime}$ $S$ and 42 $34^{\prime} 19^{\prime \prime} W$, with 133 m of altitude. According to Köeppen, regional climate is classified as a tropical megathermal climate, very warm, and dry sub-humid, with an average annual temperature of $27.8^{\circ} \mathrm{C}$ and average annual precipitation of $1200 \mathrm{~mm}$.

The soil of the experimental area is a thick sandy clay loam textured Plinthosol (Plintossolo Háplico distrófico, Brazilian Soil Classification System), with a gently-wavy relief (Embrapa, 2006).

Soil samples were collected three months before planting, in the 0 to $20 \mathrm{~cm}$ layer for physicochemical analysis in the Unithal Laboratory. The results are shown in Tables 1 and 2.

Phosphate fertilization was carried out at a depth of $0.10 \mathrm{~m}$ in the planting furrow, which was opened with a hoe on the day of planting, following the pre-established treatments. Potassium fertilization was carried out with potassium chloride at a dose of $60 \mathrm{~kg} \mathrm{~K} \mathrm{O}_{2}$ $\mathrm{ha}^{-1}$, together with FTE-BR12 at a dose of $15 \mathrm{~kg}$ $\mathrm{ha}^{-1}$, applied in the planting furrow. No nitrogen fertilization was performed considering that crop nitrogen requirements are supplied through the natural symbiotic association of bacteria of the genus Rhizobium.

Table 1. Chemical and particle size analyses of the soil of the experimental area at a depth of 0-20 cm. José de Freitas, PI, Brazil, 2013.

\begin{tabular}{|c|c|c|c|c|c|c|c|c|c|c|}
\hline \multirow{2}{*}{$\begin{array}{c}\mathrm{pH} \\
\left(\mathrm{H}_{2} \mathrm{O}\right)\end{array}$} & \multirow{2}{*}{$\begin{array}{c}\mathrm{OM} \\
\left(\mathrm{g} \mathrm{dm}^{-3}\right)\end{array}$} & $\mathrm{P}^{1}$ & $\mathrm{~K}^{1}$ & $\mathrm{Ca}^{2}$ & $\mathrm{Mg}^{2}$ & $A l^{2}$ & $\mathrm{H}+\mathrm{Al}$ & SB & $T$ & \multirow{2}{*}{$\begin{array}{c}V \\
(\%)\end{array}$} \\
\hline & & \multicolumn{2}{|c|}{$\left(\mathrm{mg} \mathrm{dm}^{-3}\right)$} & \multicolumn{6}{|c|}{$\mathrm{cmol}_{\mathrm{c}} \mathrm{dm}^{-3}$} & \\
\hline 4.8 & 8.0 & 4.0 & 0.1 & 0.3 & 0.2 & 0.6 & 2.8 & 0.6 & 3.4 & 17.6 \\
\hline \multicolumn{2}{|c|}{ Coarse sand (\%) } & & \multirow{2}{*}{\multicolumn{2}{|c|}{ Fine sand (\%) }} & \multirow{2}{*}{\multicolumn{3}{|c|}{$\begin{array}{c}\text { Silt (\%) } \\
0.8\end{array}$}} & \multirow{2}{*}{\multicolumn{2}{|c|}{$\begin{array}{c}\text { Clay (\% } \\
24.5\end{array}$}} & \\
\hline & 3.0 & & & & & & & & & \\
\hline
\end{tabular}

Table 2. Soil chemical analysis of the experimental area for micronutrients at a depth of $0-20 \mathrm{~cm}$. José de Freitas, Pl, Brazil, 2013.

\begin{tabular}{|c|c|c|c|c|c|c|}
\hline$S^{3}$ & $\mathrm{Na}^{1}$ & $\mathrm{~B}^{2}$ & $\mathrm{Fe}^{1}$ & $M n^{1}$ & $\mathrm{Cu}^{1}$ & $Z n^{1}$ \\
\hline \multicolumn{7}{|c|}{$\left(\mathrm{mg} \mathrm{dm}^{-3}\right)$} \\
\hline 3.6 & 1.0 & 0.2 & 550.0 & 1.0 & 0.8 & 1.0 \\
\hline
\end{tabular}

The experiment was carried out in a randomized complete block design with 15 treatments and four replications in a $5 \times 3$ factorial scheme. The doses 0 (control), 60, 120, 180, and $240 \mathrm{~kg} \mathrm{P} \mathrm{O}_{5} \mathrm{ha}^{-1}$ were assessed by using triple superphosphate combined with three cowpea varieties (BRS Guariba, BRS Tumucumaque, and BRS Cauamé), which have an average cycle of 65 to 70 days, semierect size, average productivity higher than $1000 \mathrm{~kg} \mathrm{ha}^{-1}$, and good commercial acceptance. The experimental units consisted of five $5 \mathrm{~m}$ long rows spaced $0.5 \mathrm{~m}$ and $0.25 \mathrm{~m}$ between pits.

The three central rows without $0.25 \mathrm{~m}$ at each end constituted the useful area of each plot, totaling $6.75 \mathrm{~m}^{2}$. Prior to experiment set-up, liming was carried out in the experimental area with a single application of a dolomitic limestone equivalent to 2.3 t ha $^{-1}$, followed by cross-plowing and harrowing three months prior to planting.

Seeds were pretreated with thiamethoxam at a dose of $300 \mathrm{~mL}$ per $100 \mathrm{~kg}$ 
of seeds. Sowing was carried out manually in the first fortnight of May 2013, placing 16 seeds per linear meter. Thinning was performed 15 days after sowing (DAS), leaving eight plants per meter, totaling 160,000 plants $\mathrm{ha}^{-1}$. Weed control was carried out by applying post-planting S-metolachlor at $1.25 \mathrm{~L} \mathrm{ha}^{-1}$ and complementary manual weeding.

Phytosanitary control was performed with a preventive spraying for pest control and a curative spraying with thiamethoxam at a dose of $200 \mathrm{~g} \mathrm{ha}^{-1}$ for controlling aphid (Aphis craccivora Koch), leafhopper (Empoasca kraemeri Ross \& Moore), and cucurbit beetle (Diabrotica speciosa).

Irrigation was carried out by means of a sprinkler with a two-day irrigation shift. Irrigation period was determined as a function of the reference evapotranspiration $100 \%$ ETo), calculated by the Penman-Monteith method by using the software Cropwat 8.0. ETo was calculated from the data of humidity, temperature, precipitation, insolation, and wind speed collected daily in the agrometeorological station of Embrapa Mid-North.

The following growth characteristics were determined: leaf area (LA, in $\left.\mathrm{cm}^{2}\right)$, determined with an electronic area meter LI-COR (Lincoln, NE, USA) model 3100; leaf area index (LAI), determined between the ratio of leaf area $\left(\mathrm{cm}^{2}\right)$ and the area occupied by the plant $\left(\mathrm{cm}^{2}\right)$; shoot dry matter (SDM, in $\mathrm{g}$ ), determined after drying the plant in a forced air ventilation oven at 65 ${ }^{\circ} \mathrm{C}$ until constant weight; and crop growth rate (CGR, in $\mathrm{g} \mathrm{m}^{-2}$ day $^{-1}$ ), variation of shoot dry matter accumulated per area in a ten-day interval. The growth data correspond to the mean of five plants per plot and assessed at 45 DAS, whereas for CGR, the data of SDM were collected at 35 and 45 DAS.

The following morphological and production characteristics were assessed: hypocotyl diameter (DHyp, in $\mathrm{mm}$ ), measured with a digital caliper below the cotyledon node; main branch length ( $\mathrm{MBL}$, in $\mathrm{cm}$ ), distance between the cotyledon node and the apex of the main branch; number of pods per plant (NPP); pod length (PL, in $\mathrm{cm}$ ); number of grains per pod (NGP); 100-grain weight (100GW, in g), randomly chosen per plot; grain production per plant (GPP, in g); and grain yield (GY, $\mathrm{kg} \mathrm{ha}^{-1}$ ). DHyp and MBL, measured at 35 DAS, and NPP and GPP, measured at 70 DAS, are the means of five plants randomly chosen per plot, while PL and NGP are the means of ten pods randomly chosen per plot. GY corresponds to the total production of dry grains per plot, with approximately $13 \%$ of moisture, converted to $\mathrm{kg} \mathrm{ha}^{-1}$. All data were collected in the useful area of the plots.

The data were submitted to analysis of variance with polynomial regression for phosphorus doses and Tukey's test for cultivars. The analyses were performed by using the software ASSISTAT 7.6 Beta.

\section{Results and discussion}

No significant effect was observed by the F-test $(p>0.05)$ for cultivars and interaction on LA, LAI, SDM, and CGR. Quadratic models $(p<0.01)$ were adjusted for LA, LAI, SDM, and CGR as a function of phosphorus doses (Figure 1). The highest increases in LA and LAI were obtained between the control and the dose of $180 \mathrm{~kg}$ $\mathrm{P}_{2} \mathrm{O}_{5}$ ha $^{-1}$, with increases of 161.2 and $160.9 \%$, respectively. The maximum values for LA $(1,372.4$ $\mathrm{cm}^{2}$ ) and LAI (2.3) were obtained with 200 and $217.7 \mathrm{~kg} \mathrm{P}_{2} \mathrm{O}_{5} \mathrm{ha}^{-1}$, respectively, indicating a tendency of reduction from these doses. Uarrota (2010) observed an increased vegetative growth and assimilation capacity in cowpea plants with phosphorus addition. Significant increases in LAI of bean related to higher doses of phosphorus were also obtained by Campos et al. (2008) and Zucareli et al. (2010).

The variable SDM showed a variation from $4.8 \mathrm{~g}$ (control) to a maximum of $13.2 \mathrm{~g}$ at a dose of $210 \mathrm{~kg} \mathrm{P}_{2} \mathrm{O}_{5} \mathrm{ha}^{-1}$, representing an increase of $175 \%$. This result shows the degree of response of cowpea to phosphate fertilization in relation to plant dry matter production, a result that corroborates that found by Bezerra et al. (2014b), who obtained increases in SDM of cowpea as a function of phosphorus availability.

The increased phosphorus doses showed a positive response in CGR, reaching a maximum of $10.7 \mathrm{~g} \mathrm{~m}^{-2}$ day $^{-1}$ at a dose of $157.5 \mathrm{~kg} \mathrm{P} \mathrm{O}_{5}$ $\mathrm{ha}^{-1}$, which represents an increase of $91.1 \%$ when compared to the control $\left(5.6 \mathrm{~g} \mathrm{~m}^{-2}\right.$ day $\left.^{-1}\right)$. 

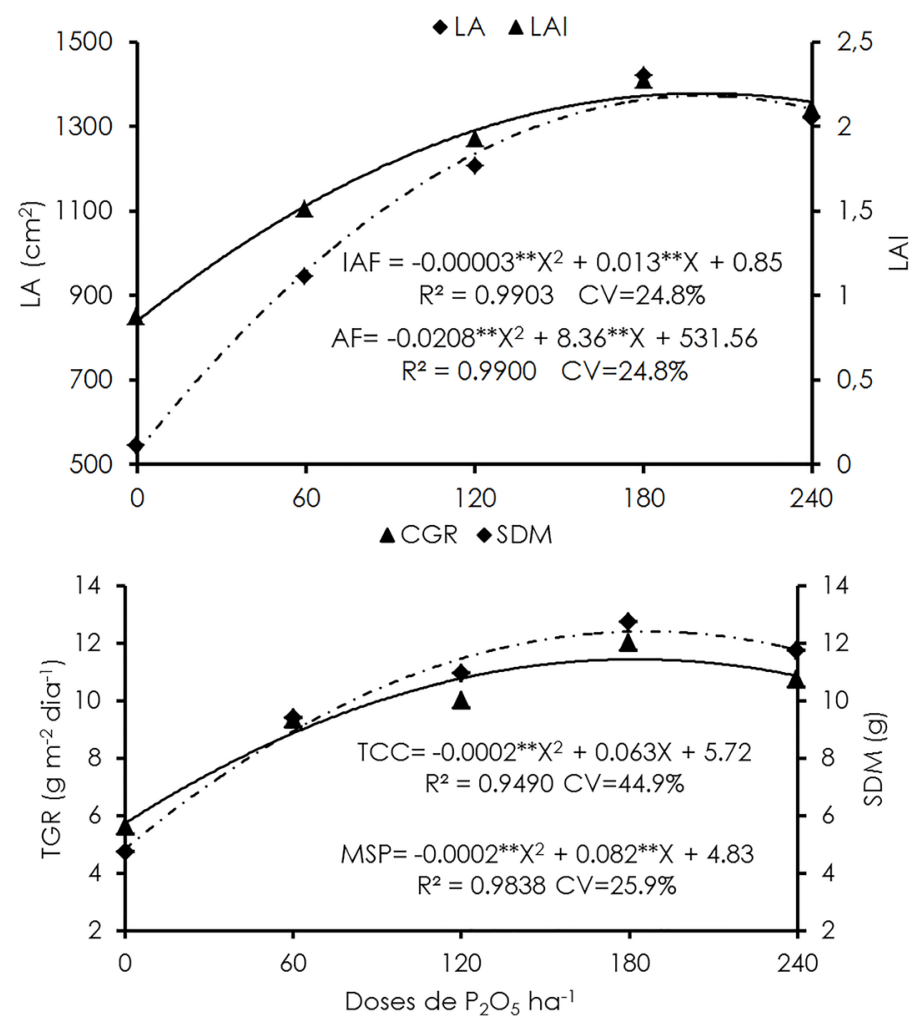

Figure 1. Leaf area (LA), leaf area index (LAI), shoot dry matter (SDM) at 35 DAS, and crop growth rate (CGR) of three cultivars of cowpea as a function of five levels of phosphate fertilization. José de Freitas, PI, Brazil, 2013.

In addition, CGR is considered one of the most important variables for the physiology of plant growth.

The effect of cultivars was not significant by the F-test ( $p>0.05$ ) for DHyp, NPP, GPP, and GY, but significant at $\mathrm{p}<0.01$ for $\mathrm{MBL}, \mathrm{PL}$, and $100 \mathrm{GW}$ and at $p<0.05$ for NGP. No significant interaction was observed between the factors of all these variables, indicating that the cultivars presented a similar response in relation to the different levels of phosphorus.

The cultivar BRS Tumucumaque stood out in relation to the productive characteristics and showed the highest value of 100GW (21.0 g) and, together with the cultivar BRS Guariba, the highest values of PL (Table 3). The variable 100GW is an important commercial characteristic for the domestic and international market of dry grains and the variable PL for the domestic market of green beans.

Table 3. Means for main branch length (MBL, in cm), pod length (PL, in cm), one-hundred-grain weight (100GW, in g), and number of grains per pod (NGP) of the three cultivars of cowpea submitted to five levels of phosphate fertilization. José de Freitas, PI, Brazil, 2013.

\begin{tabular}{lcccc}
\hline \multirow{2}{*}{ Cultivar } & \multicolumn{3}{c}{ Mean' $^{\prime}$} \\
\cline { 2 - 5 } & MBL $(\mathrm{cm})$ & $\mathrm{PL}(\mathrm{cm})$ & $100 \mathrm{GW}(\mathrm{g})$ & NGP \\
\hline BRS Cauamé & $35.7 \mathrm{a}$ & $16.1 \mathrm{~b}$ & $17.9 \mathrm{~b}$ & $9.9 \mathrm{~b}$ \\
BRS Guariba & $29.5 \mathrm{~b}$ & $19.6 \mathrm{a}$ & $18.5 \mathrm{~b}$ & $11.8 \mathrm{a}$ \\
BRS Tumucumaque & $32.5 \mathrm{ab}$ & $18.6 \mathrm{a}$ & $21.0 \mathrm{a}$ & $9.9 \mathrm{~b}$ \\
\hline LSD & 3.4 & 1.2 & 1.2 & 1.7 \\
CV\% & 13.4 & 8.9 & 6.4 & 21.3 \\
\hline
\end{tabular}

The regression analysis showed a linear adjustment for DHyp and PL and a quadratic adjustment for MBL and NPP as phosphorus doses increased (Figure 2). Increases of $98.9 \%$ for DHyp, $51.3 \%$ for $\mathrm{MBL}, 25 \%$ for $\mathrm{PL}$, and $168.4 \%$ for
NPP were observed when comparing the control with the dose of $240 \mathrm{~kg} \mathrm{P}_{2} \mathrm{O}_{5} \mathrm{ha}^{-1}$. For MBL, 96.9\% of the total increase occurred in the range of 0.0 to $180 \mathrm{~kg}$ of $\mathrm{P}_{2} \mathrm{O}_{5} \mathrm{ha}^{-1}$. These results show the direct and strong influence of phosphorus on the 
architectural (DHyp and MBL) and productive (PL and NPP) characteristics of the cultivars. Bezerra et al. (2014b) related a higher SD and MBL to a higher phosphorus availability in the soil. In fact, Taiz \& Zeiger (2009) observed that phosphorus deficiency reduces stem diameter and plant growth. Kugblenu et al. (2014) assessed six cowpea genotypes and concluded that low phosphorus levels promoted a differentiated growth.
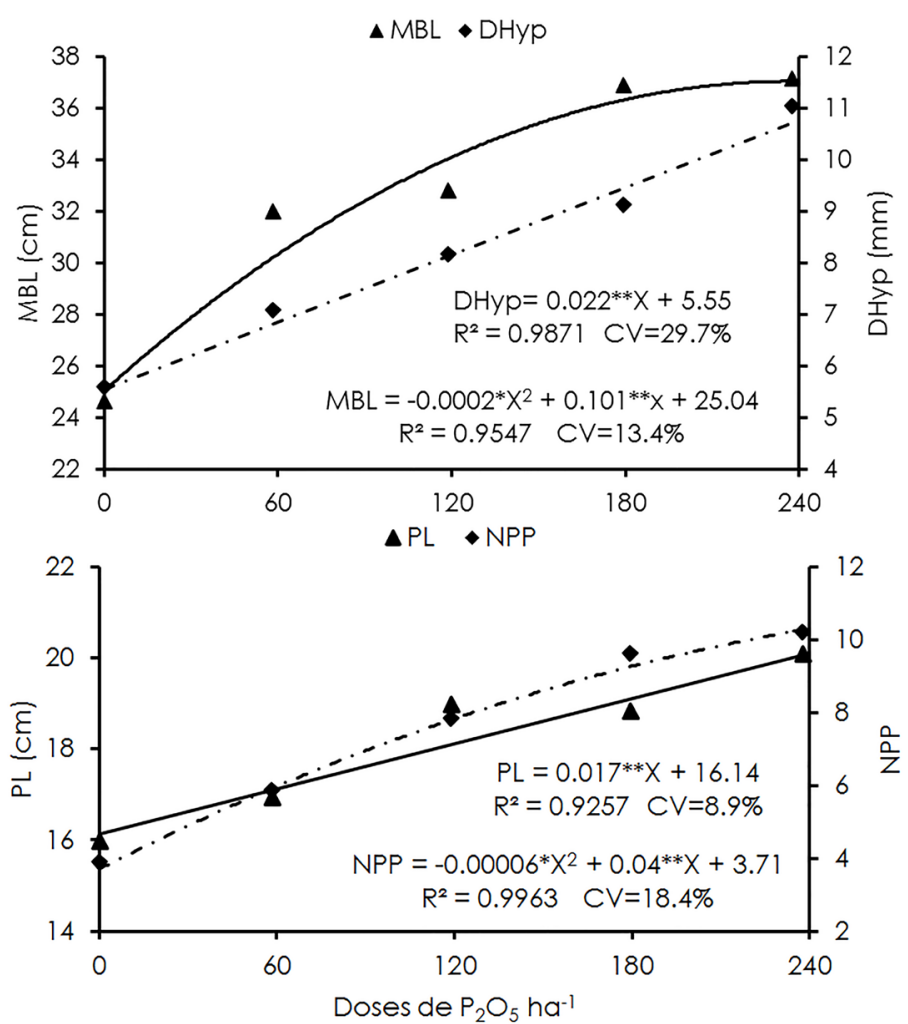

Figure 2. Main branch length (MBL), hypocotyl diameter (DHyp), pod length $(\mathrm{PL})$, and number of pods per plant (NPP) of three cultivars of cowpea as a function of five levels of phosphate fertilization. José de Freitas, PI, Brazil, 2013

The increase of $168.4 \%$ in NPP, which is the main production component in cowpea, directly impacts the yield of dry or green grains of the cultivars, while higher DHyp favors the resistance of plants to lodging. Oliveira et al. (2011) and Coutinho et al. (2014) obtained increases in DHyp and MBL in cowpea as phosphorus doses increased.

Regression analysis showed a quadratic effect for 100GW, NGO, GPP, and GY in relation to the studied phosphorus doses (Figure 3). There was a gain of $10.6 \%$ in $100 \mathrm{GW}$ when comparing the control to the dose of $180 \mathrm{~kg}$ of $\mathrm{P}_{2} \mathrm{O}_{5} \mathrm{ha}^{-1}$ and the maximum value of $100 \mathrm{GW}$ of $21.4 \mathrm{~g}$ would be obtained at a dose of $200 \mathrm{~kg}$ of $\mathrm{P}_{2} \mathrm{O}_{5} \mathrm{ha}^{-1}$. This higher accumulation of dry matter in the grain in response to the higher levels of soil $\mathrm{P}_{2} \mathrm{O}_{5}$ favors quality and commercial acceptance of the product since there is a preference, in most of the consumer markets, for larger grains. Perreira
Júnior et al. (2015), Coutinho et al. (2014), Ndor et al. (2012), Oliveira et al. (2011), and Singh et al (2011) obtained gains in 100GW on cultivars of cowpea as $\mathrm{P}_{2} \mathrm{O}_{5}$ doses increased.

The variable NGP increased from 7.5 in the control to 12.0 at a dose of $120 \mathrm{~kg}$ of $\mathrm{P}_{2} \mathrm{O}_{5}$ $\mathrm{ha}^{-1}$, which represents an increase of $52.0 \%$ and indicates that adequate levels of phosphorus in the soil favor the reproductive efficiency per pod and hence production. Coutinho et al. (2014) and Teixeira et al. (2016) obtained increases in NGP in cowpea and response to increases in phosphorus availability.

Moreover, GPP presented an increase of $372.5 \%$ when comparing the control $(4.0 \mathrm{~g})$ with the dose of $240 \mathrm{~kg} \mathrm{P}_{2} \mathrm{O}_{5} \mathrm{ha}^{-1}$ (18.9 g), and $91.9 \%$ of this increase occurred in the range between the doses 0.0 (control) and $180 \mathrm{~kg} \mathrm{P}_{2} \mathrm{O}_{5} \mathrm{ha}^{-1}$. There was a gain of $267.8 \%$ in GY when comparing the control $\left(521.2 \mathrm{~kg} \mathrm{ha}^{-1}\right)$ with the dose of $240 \mathrm{~kg}$ 

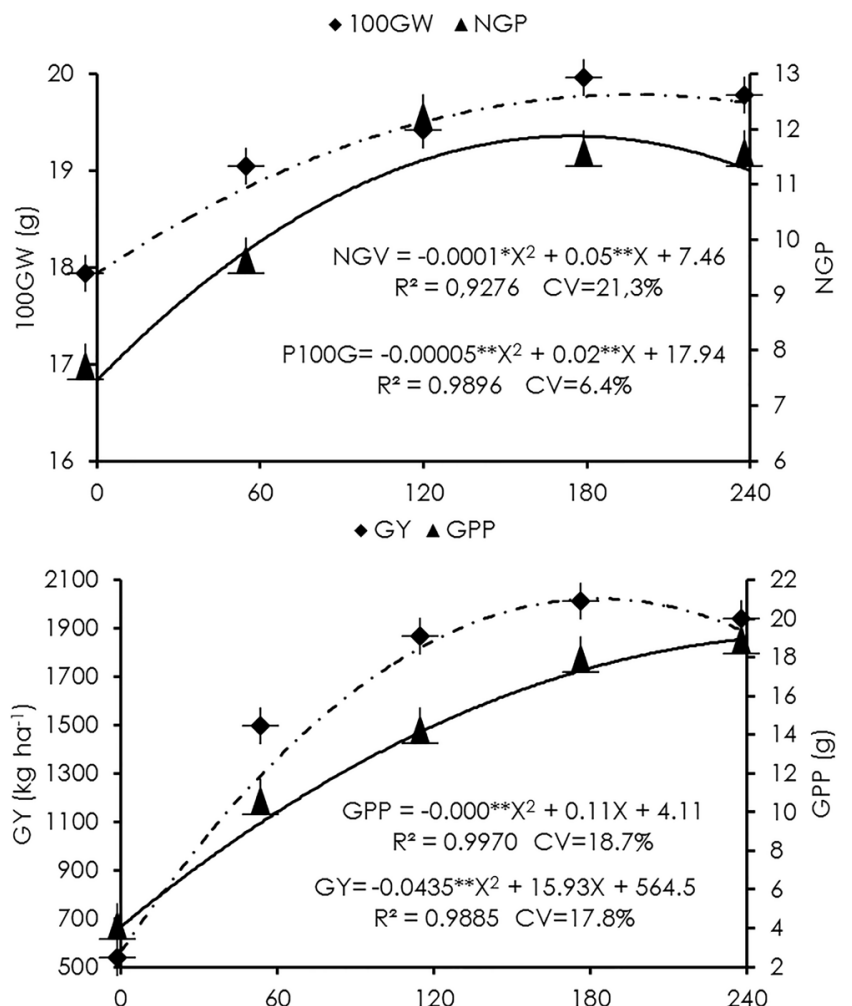

Figure 3. One-hundred-grain weight (100GW), number of grains per pod (NGP), dry grain yield (GY) and grain production per plant (GPP) of varieties as a function of the use of five levels of phosphorus. José de Freitas, PI, Brazil, 2013.

$\mathrm{P}_{2} \mathrm{O}_{5} \mathrm{ha}^{-1}\left(1,917.2 \mathrm{~kg} \mathrm{ha}^{-1}\right)$, and $93.6 \%$ of this gain were obtained in the range between the control and $180 \mathrm{~kg} \mathrm{P}_{2} \mathrm{O}_{5} \mathrm{ha}^{-1}$. The maximum GY of 2,023.1 $\mathrm{kg} \mathrm{ha}^{-1}$ would be obtained at a dose of 183.1 $\mathrm{kg} \mathrm{P}_{2} \mathrm{O}_{5} \mathrm{ha}^{-1}$. Gains in GY were due to significant increases in all production components in response to increases in soil phosphorus levels.

Silva et al. (2010) worked on a mediumtextured Oxisol (Latossolo Amarelo distrocoeso, Brazilian Soil Classification System) with doses varying from 0 to $120 \mathrm{~kg} \mathrm{P} \mathrm{O}_{5} \mathrm{ha}^{-1}$ and obtained increases in productivity with a maximum technical yield of $1,177 \mathrm{~kg} \mathrm{ha}^{-1}$ at a dose of

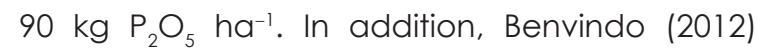
obtained a maximum grain yield of $1319 \mathrm{~kg} \mathrm{ha}^{-1}$ at a dose $168 \mathrm{~kg} \mathrm{P}_{2} \mathrm{O}_{5}$ ha $^{-1}$ in a sandy textured Entisol (Neossolo Quartzarênico, Brazilian Soil Classification System) and with the cultivar BR-17 Gurguéia. Yield gains in cowpea as a response to increases in phosphorus doses were also obtained by Singh et al. (2011), Ndor et al. (2012), Karikari et al. (2015) and Pereira Júnior et al. (2015). According to Fonseca et al. (2010), contents and accumulations of macronutrients in cowpea are influenced by $\mathrm{P}$ doses, which, together with nitrogen, are the most exported nutrients by grains.

\section{Conclusions}

The three cultivars respond similarly to the different applied phosphorus doses.

Morphophysiological and productive performance of the three cultivars is influenced by soil phosphorus levels.

The maximum technical grains yield of $2,023.25 \mathrm{~kg} \mathrm{ha}^{-1}$ is obtained at a dose of $183.1 \mathrm{~kg}$ $\mathrm{P}_{2} \mathrm{O}_{5} \mathrm{ha}^{-1}$.

\section{References}

Adetunji, M.T. 1995. Equilibrium phosphate concentration as an estimate of phosphate needs of maize in some tropical Alfisols. Tropical Agriculture 72: 285-289.

Karikari, B., Arkorful, E., Addy, S. 2015. Growth, nodulation and yield response of Cowpea to phosphorus fertilizer application in Ghana. Journal of Agronomy 14: 234-240.

Benvindo, R.N. 2012. Adubação fosfatada e potássica na nutrição e na produtividade de feijão-caupi, cultivado no município de Bom Jesus-PI. 61 f. Tese de Doutorado em Agronomia - Faculdade de Ciências Agrárias e Veterinárias, 
Universidade Estadual Paulista, "Júlio de Mesquita", Jabuticabal, Brasil.

Bezerra, A.A.C., Neves, A.C., Alcântara Neto, F., Silva Júnior, J.V. 2014a. Morfofisiologia e produção de feijão-caupi, cultivar BRS Novaera, em função da densidade de plantas. Revista Caatinga, 27: 135 - 141 .

Bezerra, M.A.F., Oliveira, F.A., Bezerra, F.T.C., Pereira, W.E., Silva, S.A. 2014b. Cultivo de feijãocaupi em Latossolos sob o efeito residual da adubação fosfatada. Revista Caatinga 27: 109 $-115$.

Campos, M.F., Ono, O.E, Boano, C.S.F., Rodrigues, J.D. 2008. Análise de crescimento em plantas de soja tratadas com substâncias reguladoras. Revista Biotemas 2: 55-63.

Carvalho, A.F.U., Sousa, N.M., Farias, D.F., Bezerra L.C.B.R., Silva, R.M.P., Viana, M.P., Gouveia, S.T., Sampaio, S.S., Sousa, M.B., Lima, G.P.G., Morais, S.M., Barros, C.C., Freire Filho, F.R. 2012. Nutritional ranking of 30 Brazilian genotypes of cowpeas including determination of antioxidant capacity and vitamins. Journal of Food Composition and Analysis 26: 81-88.

CONAB.Companhia Nacionalde Abastecimento. 2016. Grãos - Série Histórica. https:// portaldeinformacoes.conab.gov.br/index.php/ safra-serie-historica-dashboard/<Acesso em 30 Abr. 2018.

Coutinho, P.W.R., Silva, D.M.S., Saldanha, E.C.M., Okumura, R.S., Silva Júnior, M.L. 2014. Doses de fósforo na cultura do feijão-caupi na região nordeste do Estado do Pará. Revista Agro@ mbiente 8: 66-73.

Embrapa. 2006. Sistema brasileiro de classificação de solos. Rio de Janeiro, Brasil. 306 p.

Fonseca, M. R., Fernandes, A.R., Silva, G.R., Brasil, E.R. 2010. Teor e acúmulo de nutrientes por plantas de feijão-caupi em função do fósforo e da saturação por bases. Revista de Ciências Agrárias 53: 195-205.

Kugblenu, Y.O., Kumaga, F.K., Ofori, K. AduGyamfi, J.J. 2014. Evaluation of cowpea genotypes for phosphorus use efficiency. Journal of Agricultural and Crop Research 2: 202-210.

Ndor, E., Dauda, N.S., E.O. Abimuku, Azagaku, D.E., Anzaku, H. 2012. Effect of phosphorus fertilizer and spacing on growth, nodulation count and yield of cowpea [Vigna unguiculata (L) Walp] in southern guinea savanna agroecological zone, Nigeria. Asian Journal of Agricultural Sciences 4: 254-257.

Oliveira, C.T., Silva, J., Salgado, F.H.M., Sousa, S.A., Fidelis, R.R. 2012. Eficiência e resposta à aplicação de fósforo em feijão comum em solos de cerrado. Revista Verde 7: 16-24.

Oliveira, G.A., Araújo, W.F., Cruz, P.L.S., Silva, W. L. M. da; Ferreira, G.B. 2011 . Resposta do feijãocaupi as lâminas de irrigação e as doses de fósforo no cerrado de Roraima. Revista Ciência Agronômica 42: 872-882.

Pereira Junior, E. B., Oliveira, F. H. T., Oliveira, F. T., Silva, G. F., Hafle, O. M., Cruz, A. R. 2015. Adubação nitrogenada e fosfatada na cultura do feijão caupi irrigado no município de Sousa PB. Global Science and Technology 8:110-121.

Silva, A.J., Uchôa, S.C.P., Alves, J.M.A., Lima, A.C.S., Santos, C.S.V., Oliveira, J.M.F., Melo, V. F. 2010. Respostas do feijão-caupi a doses e formas de aplicação de fósforo em Latossolo Amarelo. Revista Acta Amazônia 40: 31-36, 2010.

SILVA, F.A.S. ASSISTAT: Versão 7.6 beta. Disponível em www.assistat.com. Acessado em: 20 de maio de 2016.

Singh, A., Baoule, A.L., Ahmed, H.G., Dikko, A.U., Aliyu, U., Sokoto, M. B., Alhassan, J., Musa, M., Haliru, B. 2011. Influence of phosphorus on the performance of cowpea [Vigna unguiculata (L) Walp.] varieties in the Sudan savanna of Nigeria. Agricultural Sciences 2: 313-317.

Smyth, T.J., Cravo, M.S. (1990) Critical phosphorus levels for corn and cowpea in a Brazilian Oxisol. Agronomy Journal, 82: 309-312.

Taiz, L., Zeiger, E. 2009. Fisiologia Vegetal. 4. ed. Artmed editora, 848p.

Teixeira, P.E.G., Fernandes, A.R., Galvão, J.R., Pereira, W.V.S., Casanova, S.R.A; Alves Filho, P.P.C. 2016. Cowpea yield on soils with residues of NPK and natural phosphate fertilizers in succession the area of degraded pasture. Revista Ceres 63: 553-567.

Uarrota, V.G. 2010. Response of cowpea (Vigna unguiculata L. Walp.) to water stress and phosphorous fertilization. Jornal of Agronomy 9: 87-91.

Zucareli, C., Ramos Júnior, E.U., Oliveira, M.A., Carvariani, C., Nakagawa, J. 2010. Índices biométricos e fisiológicos em feijoeiro sob diferentes doses de adubação fosfatada. Revista Ciências Agrárias 31: 1313-1324. 